\title{
Colloguium
}

\section{Nutrient Management Practices in Perennial Strawberry are Informed by Understanding the Relationships among Carbohydrate Status, Nitrogen Availability, and Soil Composition}

\author{
Marvin P. Pritts ${ }^{1}$
}

AdDITIONAL INDEX wORDs. Fragaria $\times$ ananassa, foliar analysis, leaf tissue standards, macronutrients, soil $\mathrm{pH}$, soil testing

Summary. Strawberry (Fragaria $\times$ ananassa) is a perennial plant with a compressed woody crown that responds to the environment in a similar way as other temperate fruit crops. Nutrient management practices are also similar, with a few exceptions. Levels of preplant amendments are determined based on soil test results, and are used to increase nutrient availability and modify $\mathrm{pH}$ as needed. Once plants are established, soil tests, coupled with foliar tissue analysis and observations of plant growth, are the best indicators of plant nutrient status and limitations. Drip irrigation is more efficient than granular applications for supplying soluble nutrients such as nitrogen $(\mathrm{N})$. While most temperate fruit crops respond well to $\mathrm{N}$ in spring when growth resumes after winter, applications of spring $\mathbf{N}$ in strawberry can cause excessive vegetative growth, reduce fruit quality, and have only a marginal impact on yield. $\mathrm{N}$ is most efficiently taken up by plants when conditions favor root growth, and $\mathrm{N}$ applied in summer or fall is more effective at increasing yield the following spring, assuming that the carbohydrate status of the plant is good. However, if carbohydrate status is poor, supplemental $\mathrm{N}$ late in the season can reduce yield by requiring additional carbon $(\mathrm{C})$ for $\mathrm{N}$ uptake. Many questions remain to better understand how to manage nutrients optimally in perennial strawberry.

$\mathrm{M}$ ost strawberry production occurs in annual systems in warm climates, but significant acreage of perennial strawberry exists in north temperate regions of the world. The strawberry plant is naturally a perennial that responds to the environment in a similar way

Horticulture Section, School of Integrative Plant Science, Cornell University, Ithaca, NY 14853

This paper was part of the colloquium "Recent Advances in Perennial Berry Crop Nutrition and Directions for Future Research" held on 28 July 2014 at the ASHS Annual Conference in Orlando, FL, and sponsored by the Viticulture and Small Fruit (VSF) Working Group.

${ }^{1}$ Corresponding author. E-mail: mpp3@cornell.edu. as other temperate fruit crops. While the herbaceous aboveground portion of the strawberry plant is most visible, the woody crown can extend to $60 \mathrm{~cm}$ in the case of beach strawberry [Fragaria chiloensis(Darrow, 1966)]. Under the influence of short days, strawberry plants accumulate starch and mobilize nutrients from leaves to roots and crowns as do most perennials (Darrow, 1966), even in cultivars where flower induction is insensitive to daylength (Acuña-Maldonado and Pritts, 2013). Although strawberry leaves are not strictly deciduous, many will die before the onset of winter. The general approach to nutrient management in perennial strawberry production is not dissimilar to management in temperate tree fruit and grape (Vitis sp.) crops (May and Pritts, 1990).

\section{Standard preplant practices}

Before strawberries are planted, soil testing is recommended and adjustments are made to $\mathrm{pH}$, phosphorus $(\mathrm{P})$, potassium $(\mathrm{K})$, calcium $(\mathrm{Ca})$, magnesium $(\mathrm{Mg})$, and boron $(\mathrm{B})$. Organic matter additions may be recommended as well if the level is below $4 \%$. Pritts et al. (2015) describe soiltesting methodology for strawberry in detail. The goal of amending the soil before planting is to provide sufficient macronutrients, except $\mathrm{N}$, for the remaining life of the planting. Soil test recommendations for strawberry have been developed based on experience and on how other crops have responded to nutrient additions. Unlike most field crops, standard nutrient response curves for various essential nutrients typically have not been developed for perennial strawberry in different soils.

Once plants are established, foliar testing, together with soil tests, provide insight into the nutrient status of the plant, assuming that the soil $\mathrm{pH}$ remains within the recommended range of 6.0 to 6.8 . On sandier soils or where extensive irrigation is used, supplementation of $\mathrm{P}, \mathrm{K}, \mathrm{Mg}$, and micronutrients may be required in the years after planting. In soils with a limestone base, supplementation with sulfuric acid or other acidifying material may be needed to maintain the $\mathrm{pH}$ within an acceptable range.

\section{Standard postplant practices}

A soil test is sometimes used as the sole basis for a fertilizer recommendation

\begin{tabular}{llll}
\hline $\begin{array}{l}\text { Units } \\
\begin{array}{l}\text { To convert U.S. to SI, } \\
\text { multiply by }\end{array}\end{array}$ & U.S. unit & SI unit & $\begin{array}{l}\text { To convert SI to U.S., } \\
\text { multiply by }\end{array}$ \\
\hline 0.4536 & $\mathrm{lb}$ & $\mathrm{kg}$ & 2.2046 \\
1.1209 & $\mathrm{lb} / \mathrm{acre}$ & $\mathrm{kg} \cdot \mathrm{ha}^{-1}$ & 0.8922 \\
28.3495 & $\mathrm{oz}$ & $\mathrm{g}$ & 0.0353 \\
$\mathrm{l}$ & $\mathrm{ppm}$ & $\mathrm{mg} \cdot \mathrm{kg}^{-1}$ & $\mathrm{l}$
\end{tabular}


after planting, but this alone is not a good reflection of the nutrient status of the strawberry plant. Nutrient uptake from soil is affected by factors such as $\mathrm{pH}$, soil water status, disease, microbiological activity, and various nutrient interactions, so the level of a nutrient in the soil is often poorly correlated with availability to the plant. For example, a biologically active soil may have a more rapid release of $\mathrm{N}$ and other nutrients from the mineral and organic matter fractions of the soil (Swift et al., 1979). Rhizoctonia root rot (Rbizoctonia fragariae), a known pathogen of strawberry, can enhance nutrient uptake and growth under certain conditions by functioning similarly to mycorrhizae (Scott et al., 2004). Plants grown in soils high in $\mathrm{P}$ may have low $\mathrm{P}$ in leaves if $\mathrm{B}$, essential for root growth, is also low in the soil due to interactions among the two (May and Pritts, 1993).

Adjustments to nutrient supply are most accurately based on a combination of foliar and soil test results rather than on soil test results alone. A foliar analysis has several advantages over soil tests: 1) the foliar test provides a snapshot of how much nutrient is in the plant-not simply how much is available in the soil; 2) a foliar analysis can detect a low nutrient level before it has a negative effect on growth or yield; and 3) a foliar analysis is informative for all essential macro and micronutrients, whereas soil tests provide little value to guide management of micronutrients or $\mathrm{N}$. When soil tests are used together with foliar analyses and close observations of plant growth, considerable insight into what might be causing nutrient limitations can be revealed (Pritts et al., 2015).

\section{Timing and rates of $\mathbf{N}$ application}

The standard recommended rates and timings for $\mathrm{N}$ applications are different from other perennial fruit crops. The root system of strawberry is $\approx 10 \%$ to $20 \%$ of the total plant biomass (May et al., 1994; Strik et al., 2004) and is not particularly efficient at acquiring $\mathrm{N}$ from the soil. Maximum fertilizer use efficiencies are typically less than $60 \%$ (Strik et al., 2004). Therefore, $\mathrm{N}$ is most efficiently used when applied at regular intervals in soluble form. If a grower has drip irrigation, then up to $0.5 \mathrm{lb}$ per day of actual $\mathrm{N}$ (3.5 lb per week) is applied during the growing season based on standard plant spacing. $\mathrm{N}$ rates are typically lower during fruiting and higher after fruiting, whereas higher amounts of $\mathrm{K}$ may be applied during fruiting when plant demand is greatest. However, if a grower does not have drip irrigation, then granular applications are used. In the planting year, a typical application date and rate would be $30 \mathrm{lb} /$ acre a few weeks after planting, and then another $30-40 \mathrm{lb} /$ acre in midlate August (Hart et al., 2000; Pritts and Handley, 1998). In the fruiting year, the first of the two applications is not made until after harvest. The largest portion is applied at renovation (ranging from 50 to $70 \mathrm{lb} /$ acre) followed in some areas by a second, smaller application in fall of up to $30 \mathrm{lb} /$ acre. Rates are adjusted downward where organic matter is high or growth is vigorous or upward when extensive irrigation is used or soils are sandy.

Many perennial crops are fertilized with $\mathrm{N}$ when vegetative growth begins in spring. However, $\mathrm{N}$ fertilization in spring of the fruiting year is generally not recommended in perennial strawberry because too much spring $\mathrm{N}$ can be detrimental to the plants and fruit, or simply not be economical to apply. Yield responses to spring fertilization were not observed in the Pacific northwestern United States, either with granular or foliar $\mathrm{N}$ applications, although vegetative growth was increased (Breen and Martin, 1981; Strik et al., 2004). Ulrich and Martin (1987) and Kirsch (1959) reported negative effects on fruit quality from springapplied $\mathrm{N}$, but not with all cultivars. In another study, doubling $\mathrm{N}$ above what is considered an optimal rate increased leaf area by $50 \%$ but yield by only $12 \%$ (Acuña-Maldonado and Pritts, 2009). Applying $30 \mathrm{lb} /$ acre in spring before fruiting resulted in excessive vegetative growth and increased gray mold (Botrytis cinerea) on fruit in each of 3 years (Cooley et al., 1996).

$\mathrm{N}$ fertilizer applied early in the growing season is often assimilated into leaf and crown tissue (Table 1), but less into roots as they do not grow much where summers are hot (Kadir et al., 2006) and because fruiting suppresses root uptake (Archbold and MacKown, 1995). Foliar N applications during fruiting resulted in partitioning of $\mathrm{N}$ to leaves with little to roots (Nestby and Tagliavini, 2005; Strik et al., 2004). They reported that partitioning of foliarapplied $\mathrm{N}$ to fruits also occurs, but found no effects on yield. During longer growing seasons that result in an early harvest season, or in climates with relatively cool summers, strawberry roots and crowns can acquire a significant amount of $\mathrm{N}$ from fertilizer when applied postharvest in summer (Strik et al., 2004). In climates with warmer summers, the most

Table 1. Percent nitrogen $(\mathrm{N})$ derived from applications of granular fertilizer in various plant parts of first-year field-planted 'Jewel' strawberry 3 weeks after application date and at the end of the growing season (21 Nov.). A total of five applications of $20 \mathrm{~kg} \cdot \mathrm{ha}^{-1}(17.8 \mathrm{lb} /$ acre $) \mathrm{N}$ was made throughout the season to each treatment, 3 weeks apart, beginning on 21 June. On the application date indicated, labeled ${ }^{15} \mathrm{~N}$ fertilizer urea (10.0 atom \%) was substituted for standard urea (Acuña-Maldonado, 2005).

\begin{tabular}{|c|c|c|c|c|c|c|c|c|}
\hline $\begin{array}{l}\text { Application } \\
\text { date }\end{array}$ & $\begin{array}{c}\text { Sample } \\
\text { date }\end{array}$ & Leaves & $\begin{array}{l}\text { N (\%) } \\
\text { Crowns }\end{array}$ & Roots & $\begin{array}{c}\text { Sample } \\
\text { date }\end{array}$ & Leaves & $\begin{array}{c}\text { N (\%) } \\
\text { Crowns }\end{array}$ & Roots \\
\hline 21 June & 10 July & 27.0 & 19.0 & 16.2 & & & & \\
\hline 25 July & 12 Aug. & 14.6 & 55.5 & 9.0 & 21 Nov. & 38.2 & 47.1 & 29.2 \\
\hline 30 Aug. & 17 Sept. & 47.9 & 25.5 & 28.1 & 21 Nov. & 39.0 & 55.5 & 51.3 \\
\hline 25 Sept. & 9 Oct. & 27.5 & 23.1 & 27.2 & 21 Nov. & 20.4 & 25.5 & 47.5 \\
\hline 21 Oct. & 8 Nov. & 11.9 & 26.9 & 63.3 & 21 Nov. & 9.5 & 23.1 & 55.7 \\
\hline LSD $(0.05)^{\mathrm{z}}$ & & 12.0 & 9.9 & 10.8 & & 13.2 & 14.2 & 21.6 \\
\hline
\end{tabular}

${ }^{\mathrm{z}}$ Least significant difference (LSD) at $P \leq 0.05$. 


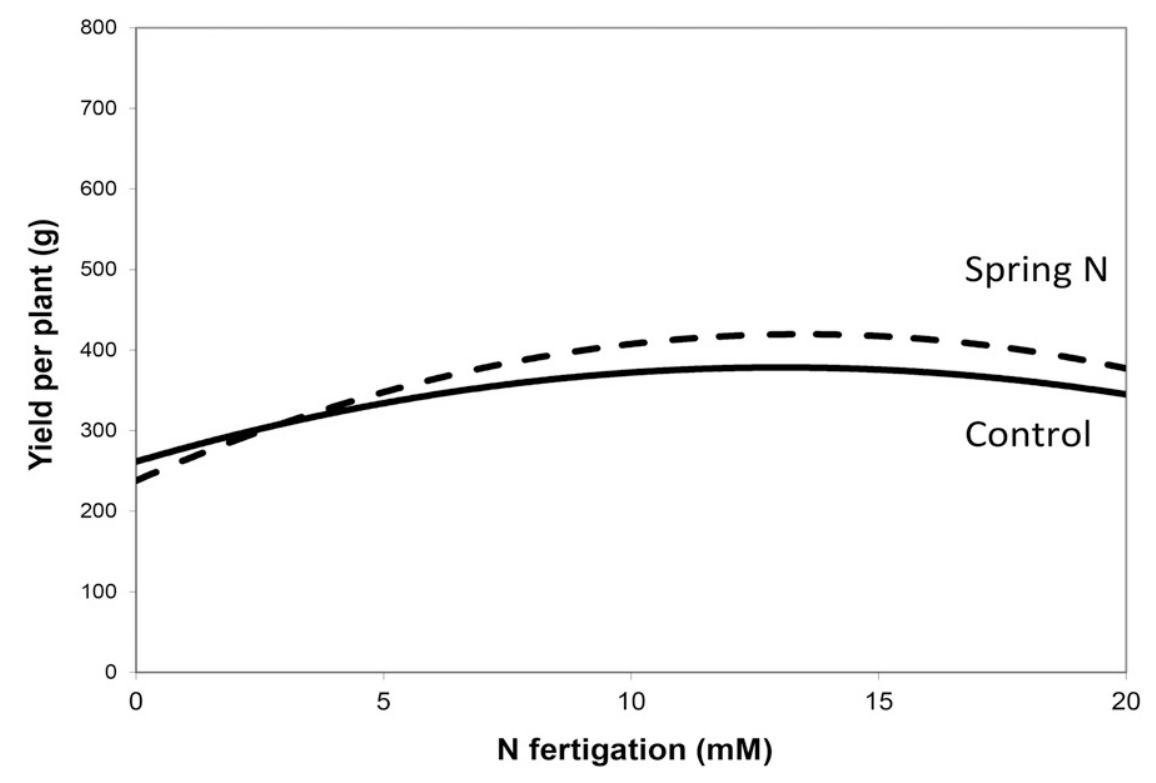

Fig. 1. Yield response of 'Jewel' strawberry in the fruiting year to various nitrogen (N) fertigation rates in the planting year $(0-20 \mathrm{~mm}$ in the fertilizer solution $)$ and to + or - additional spring $\mathrm{N}\left[30 \mathrm{~kg} \cdot \mathrm{ha}^{-1}(26.8 \mathrm{lb} / \mathrm{acre})\right]$ as urea in May. $R^{2}=0.094$ and 0.199 for control and spring $\mathrm{N}$, respectively (Acuña-Maldonado, 2005); $1 \mathrm{~g}=$ 0.0353 oz.

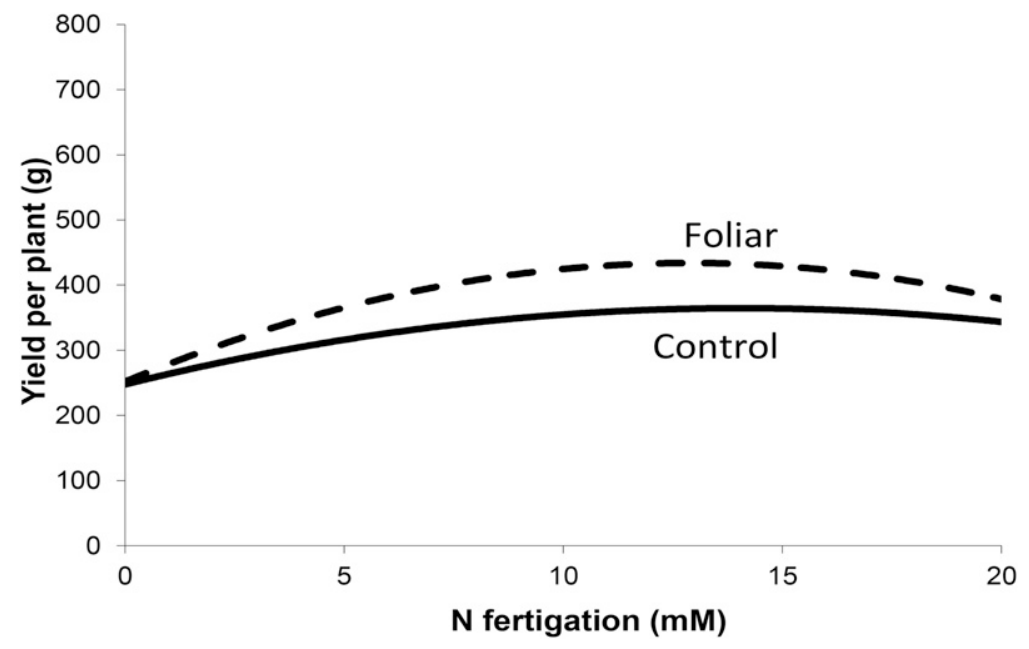

Fig. 2. Yield response of 'Jewel' strawberry in the fruiting year to various nitrogen (N) fertigation rates in the planting year $(0-20 \mathrm{~mm}$ in the fertilizer solution) and to + or - additional foliar $\mathrm{N}$ as urea $\left[5 \mathrm{~kg} \cdot \mathrm{ha}^{-1}(4.5 \mathrm{lb} / \mathrm{acre})\right]$ in October. $R^{2}=0.109$ and 0.186 for control and foliar N, respectively (Acuña-Maldonado, 2005); $1 \mathrm{~g}=$ 0.0353 oz.

active uptake of $\mathrm{N}$ appears to occur later in the season when root growth is more active.

Acuña-Maldonado (2005) found that fertilizing late in the season resulted in considerably more $\mathrm{N}$ in roots before winter (Table 1 ). Whereas spring fertilization had little impact on yield (Fig. 1), fall fertilization appeared to enhance the $\mathrm{N}$ status of roots, which can result in higher yields the following spring (Fig. 2).
Breen and Martin (1981) also reported that yield was highly correlated with percent $\mathrm{N}$ in leaves in November before harvest, and that the highest $\mathrm{N}$ fertilization levels did not always result in the highest percent leaf $\mathrm{N}$ or yield the following year. Albregts and Howard $(1980,1986)$ reported a response to foliar urea under low nutrient conditions. Daugaard and Todsen (1999) found that residual $\mathrm{N}$ in soil in winter was correlated with yield, and Archbold and MacKown (1995) found that the fruit crop uses more stored $\mathrm{N}$ than newly absorbed $\mathrm{N}$. These studies suggest that $\mathrm{N}$ status in fall and winter is associated with spring yield, but excessive $\mathrm{N}$, particularly in spring, can be detrimental or only marginally beneficial to yield.

\section{Foliar nutrient analyses}

Typical $\mathrm{N}$ fertilization rates are adjusted based on a foliar analysis. Foliar levels of all nutrients fluctuate during the growing season, so sampling is usually done on new leaves emerging after renovation when foliar levels are more stable (May et al., 1994). Standard ranges for perennial strawberry (Table 2) are remarkably similar to those for other perennial crops, with the exception of highbush blueberry [Vaccinium corymbosum (Pritts et al., 2015)].

Practitioners assume that sampling leaves after harvest is the best time to assess foliar nutrient concentrations because levels are most stable then, but it is possible that other sampling dates provide a better indicator of plant nutrient status for a particular element. Practitioners also assume that the leaf blade is the tissue that best reflects plant nutrient status, yet the petiole or crown might be a better indicator. For example, grape growers typically sample grape petioles during bloom for an accurate determination of plant nutrient status (Winkler et al., 1974). Other nonstandard times and plant parts may provide better insight as to the nutritional status of strawberry. Daugaard (2007) suggests a sampling date at the beginning of flowering, particularly for guiding $\mathrm{N}$ fertilization. Furthermore, certain nutrients may be present in the plant, but in a form that is unavailable for biological processes. The element may be in an inactive ionic state [e.g., iron $\left(\mathrm{Fe}^{+3}\right)$ or manganese $\left.\left(\mathrm{Mn}^{+4}\right)\right]$, or it may be in precipitate form, e.g., calcium phosphate $\left[\mathrm{Ca}_{3}\left(\mathrm{PO}_{4}\right)_{2}\right]$. Understanding when and how best to sample the plant and what parts to sample for optimal results remain research challenges.

\section{Interactions between $\mathrm{N}$ and $\mathrm{C}$ within the plant}

The carbohydrate status of the plant can interact with $\mathrm{N}$ uptake and utilization. Plants usually grow better 
Table 2. Standard foliar nutrient concentrations for healthy young leaves of strawberry sampled after renovation in north temperate growing regions of the eastern and western United States (Pritts et al., 2015; Strik, 2013). Values are reported as either percent or parts per million of total dry weight.

\begin{tabular}{lcc}
\hline \multicolumn{3}{c}{ Foliar nutrient concn $^{\mathrm{z}}$} \\
\hline Nutrient & Eastern United States & Western United States \\
\hline Nitrogen & $2.0 \%-2.8 \%$ & $2.5 \%-3.0 \%$ \\
Potassium & $1.5 \%-2.5 \%$ & $1.0 \%-2.0 \%$ \\
Phosphorus & $0.25 \%-0.40 \%$ & $0.15 \%-0.3 \%$ \\
Calcium & $0.7 \%-1.7 \%$ & $1.0 \%-2.0 \%$ \\
Magnesium & $0.3 \%-0.5 \%$ & $0.20 \%-0.5 \%$ \\
Boron & $30-70 \mathrm{ppm}$ & $25-45 \mathrm{ppm}$ \\
Manganese & $50-200 \mathrm{ppm}$ & $50-650 \mathrm{ppm}$ \\
Iron & $60-250 \mathrm{ppm}$ & $60-200 \mathrm{ppm}$ \\
Copper & $6-20 \mathrm{ppm}$ & $6-20 \mathrm{ppm}$ \\
Zinc & $20-50 \mathrm{ppm}$ & $20-50 \mathrm{ppm}$ \\
\hline
\end{tabular}

${ }^{2} 1 \mathrm{ppm}=1 \mathrm{mg} \cdot \mathrm{kg}^{-1}$.

and yield more when grown under supplemental carbon dioxide $\left[\mathrm{CO}_{2}\right.$ (Bushway and Pritts, 2002; Chen et al., 1997a, 1997b, 1997c)] and the total yield of a strawberry plant is closely correlated with the total nonstructural carbohydrates (TNSC) in the plant (Acuña-Maldonado and Pritts, 2009). However, when TNSC is limited, too much $\mathrm{N}$ can result in a yield decrease (Acuña-Maldonado and Pritts, 2009). C and $\mathrm{N}$ pool sizes change in opposite directions in strawberry plants, and $\mathrm{N}$ fertilization in autumn reduces starch concentration over winter, particularly in roots (Acuña-Maldonado and Pritts, 2013). This is likely due to the energy-intensive requirement of $\mathrm{N}$ assimilation that requires $\mathrm{C}$ (Cheng and Fuchigami, 2002). Starch levels are low in spring after a long period of respiration without much photosynthesis during winter (AcuñaMaldonado and Pritts, 2009). Also, in colder regions, plants often are under straw mulch or snow for winter. The limited response to spring $\mathrm{N}$ fertilization could be due to the additional suppression of TNSC reserves with increased $\mathrm{N}$ uptake.

\section{Research challenges}

Since the optimal $\mathrm{N}$ fertilization rate appears to be related to the $\mathrm{C}$ status of the plant, practitioners want to measure the TNSC status to better determine $\mathrm{N}$ rates and forms. Knowing how to relate TNSC status to optimal $\mathrm{N}$ application rate is a research challenge, since active $\mathrm{C}$ is present in different and dynamic forms in the plant. Another challenge is to know how to balance foliar and soil applications, with appropriate timings, to most efficiently and effectively use fertilizers. Particularly important is to understand this relationship for $\mathrm{N}$ since it has such a significant impact on plant growth as well as the environment. Third, nutrient levels interact within strawberry plants, possibly affecting growth and yield (May and Pritts, 1993). The number of potential interactions among nutrients is very large, and little research has been conducted to identify the most critical interactions in strawberry (Kirsch, 1959; Zurawicz and Stushnoff, 1977). Furthermore, which plant part to sample and what time to optimally sample to best determine nutrient status is not known with certainty. Finally, practitioners need to know under what conditions spring $\mathrm{N}$ is warranted. Many growers apply $\mathrm{N}$ in spring, believing that it enhances growth. Although spring $\mathrm{N}$ may indeed enhance vegetative growth, it might have little effect on yield, and could even reduce fruit quality and negatively impact the environment. Finally, we are aware that others have observed different trends under different conditions, so generalizations may not be accurate in all circumstances. Understanding how climate and management practices affect nutrient needs will continue to challenge researchers for years to come.

\section{Literature cited}

Acuña-Maldonado, L. 2005. Carbon and nitrogen reserve status and partitioning affect growth and yield in the perennial strawberry (Fragaria Xananassa Duch.). Cornell Univ., Ithaca, NY, MS Thesis.

Acuña-Maldonado, L. and M.P. Pritts. 2009. Carbon and nitrogen reserves in perennial strawberry affect plant growth and yield. J. Amer. Soc. Hort. Sci. 133:735742 .

Acuña-Maldonado, L. and M. Pritts. 2013. Seasonal patterns of carbohydrate and nitrogen accumulation and depletion in strawberry are affected by fruiting but not day neutrality. J. Amer. Pomol. Soc. 67:95-103.

Albregts, E.E. and C.M. Howard. 1980. Accumulation of nutrients by strawberry plants and fruit grown in annual hill culture. J. Amer. Soc. Hort. Sci. 105:386388 .

Albregts, E.E. and C.M. Howard. 1986. Response of strawberries to soil and foliar fertilizer rates. HortScience 21:11401142.

Archbold, D. and C. MacKown. 1995. Seasonal and cropping effects on total and fertilizer nitrogen use in June-bearing and day-neutral strawberries. J. Amer. Soc. Hort. Sci. 120:403-408.

Breen, P.J. and L.W. Martin. 1981. Vegetative and growth responses of three strawberry cultivars to nitrogen. J. Amer. Soc. Hort. Sci. 106:266-272.

Bushway, L.J. and M.P. Pritts. 2002. Enhancing early spring microclimate to increase carbon resources and productivity in June-bearing strawberry. J. Amer. Soc. Hort. Sci. 127:415-422.

Chen, K., G. Hu, N. Keutgen, and F. Lenz. 1997a. Effects of $\mathrm{CO}_{2}$ concentration on strawberry. I. Plant growth analysis. J. Appl. Bot. 71:168-172.

Chen, K., G. Hu, N. Keutgen, and F. Lenz. 1997b. Effects of $\mathrm{CO}_{2}$ concentration on strawberry. III. Dry matter production and water consumption. J. Appl. Bot. 71:179-182.

Chen, K., G. Hu, and F. Lenz. 1997c. Effects of $\mathrm{CO}_{2}$ concentration on strawberry. IV. Carbohydrate production and accumulation. J. Appl. Bot. 71:183-188.

Cheng, L. and L.H. Fuchigami. 2002. Growth of young apple trees in in relation to reserve nitrogen and carbohydrates. Tree Physiol. 22:1297-1303.

Cooley, D.R., W.F. Wilcox, J. Kovach, and S.G. Schloemann. 1996. Integrated pest management programs for strawberries in the northeastern United States. Plant Dis. 80:228-237.

Darrow, G.M. 1966. The strawberry. Holt Rinehart Winston, New York, NY. 
Daugaard, H. 2007. Leaf analysis in strawberries: Effects of cultivar, plant age, and sampling time on nutrient levels. J. Plant Nutr. 30:549-556.

Daugaard, H. and T. Todsen. 1999. Nitrogen fertilization of strawberries: $\mathrm{N}_{\min }$, leaf dry matter, and leaf sap analyses as control methods. J. Plant Nutr. 22:16791685.

Hart, J., T. Righetti, A. Sheets, and L.W. Martin. 2000. Strawberries Fertilizer Guide (Western Oregon-West of Cascades). 1 Apr. 2015. <http://www. oregon-strawberries.org/attachments/ strawberry_fertilizer_guidel4-e.pdf>.

Kadir, S., G. Sidhu, and K. Al-Khatib. 2006. Strawberry (Fragaria Xananassa Duch.) growth and productivity as affected by temperature. HortScience 41:14231430 .

Kirsch, R.K. 1959. The importance of interaction effects in fertilizer and lime studies with strawberries. Proc. Amer. Soc. Hort. Sci. 73:181-188.

May, G.M. and M.P. Pritts. 1990. Strawberry nutrition. Adv. Strawberry Production 9:10-24.
May, G.M. and M.P. Pritts. 1993. Phosphorus, zinc and boron influence yield components in 'Earliglow' strawberry. J. Amer. Soc. Hort. Sci. 118:43-49.

May, G.M., M.P. Pritts, and M.J. Kelly. 1994. Seasonal patterns of growth and tissue nutrient content in strawberries. J. Plant Nutr. 17:149-162.

Nestby, R. and M. Tagliavini. 2005. Foliar uptake and partitioning of urea- $\mathrm{N}$ by strawberry plants as affected by timing of supply and plant $\mathrm{N}$ status. J. Hort. Sci. Biotechnol. 80:272-275.

Pritts, M.P. and D. Handley. 1998. Strawberry production guide, Pub. p. 88 . Northeast Reg. Agr. Eng. Serv., Ithaca, NY. p. 162.

Pritts, M.P., M.C. Heidenreich, L. McDermott, and J. Miller. 2015. Berry Soil and Nutrient Management-A Guide for Educators and Growers. 1 Apr. 2015. $<$ http://fruit.cornell.edu/berry/ production/soilnutrientmgmt/pdfs/ BerrySoilandNutrientManagementGuide. pdf>.

Scott, R., M. Pritts, and M.J. Kelly. 2004. Effects of Rhizoctonia fragariae infection on growth and productivity of strawberry plants grown under different temperature regimes. Adv. Strawberry Production 2:26-33.

Strik, B.C. 2013. Nutrient Management in Berry Crops in Oregon. 1 Apr. 2015. <http://www.oregon-strawberries.org/ attachments/2013-May_Nutrient_ Management_Berry_Crops_OSU.pdf $>$.

Strik, B., T. Righetti, and G. Buller. 2004. Influence of rate, timing and method of nitrogen fertilization application on uptake and use of fertilizer nitrogen, growth and yield of June-bearing strawberry. J. Amer. Soc. Hort. Sci. 129:165-174.

Swift, M.J., O.W. Heal, and J.M. Anderson. 1979. Decomposition in terrestrial ecosystems. Blackwell, Oxford, UK.

Ulrich, G. and L. Martin. 1987. Spring applications of nitrogen on strawberries. Proc. Oregon Hort. Soc. 78:142-146.

Winkler, A.J., J.A. Cook, W.M. Kliewer, and L.A. Lider. 1974. General viticulture. Univ. California Press, Los Angeles, CA.

Zurawicz, E. and C. Stushnoff. 1977. Influence of nutrition on cold tolerance of 'Readcoat' strawberries. J. Amer. Soc. Hort. Sci. 102:342-346. 